慶應義塾大学学術情報リポジトリ

Keio Associated Repository of Academic resouces

\begin{tabular}{|c|c|}
\hline Title & Enkephalin but not morphine modulates the motor activity in the frog spinal cord in vitro \\
\hline \multicolumn{2}{|l|}{ Sub Title } \\
\hline Author & $\begin{array}{l}\text { 鈴木，岳之(Suzuki, Takeshi) } \\
\text { 岡, 淳一郎(Oka, Junichiro) } \\
\text { 永野，伸郎(Nagano, Nobuo) } \\
\text { 福田，英臣(Fukuda, Hideomi) }\end{array}$ \\
\hline Publisher & 共立薬科大学 \\
\hline Publication year & 1986 \\
\hline Jtitle & $\begin{array}{l}\text { 共立薬科大学研究年報 (The annual report of the Kyoritsu College of } \\
\text { Pharmacy). No.31 (1986. ) ,p.74- } 74\end{array}$ \\
\hline \multicolumn{2}{|l|}{ JaLC DOI } \\
\hline \multicolumn{2}{|l|}{ Abstract } \\
\hline Notes & 抄録 \\
\hline Genre & Technical Report \\
\hline URL & $\begin{array}{l}\text { https://koara.lib.keio.ac.jp/xoonips/modules/xoonips/detail.php?koara_id=AN00062898-0000003 } \\
\text { 1-0074 }\end{array}$ \\
\hline
\end{tabular}

慶應義塾大学学術情報リポジトリ(KOARA)に掲載されているコンテンツの著作権は、それぞれの著作者、学会または出版社/発行者に帰属し、その権利は著作権法によって 保護されています。引用にあたっては、著作権法を遵守してご利用ください。

The copyrights of content available on the KeiO Associated Repository of Academic resources (KOARA) belong to the respective authors, academic societies, or publishers/issuers, and these rights are protected by the Japanese Copyright Act. When quoting the content, please follow the Japanese copyright act. 


\title{
Enkephalin But Not Morphine Modulates The Motor Activity in the Frog Spinal Cord In Vitro
}

Takeshi Suzuki, Jun-ichiro Oка*, Nobuo Nagano* and Hideomi Fukuda*

\author{
鈴木岳之, 岡 淳一郎, * 永野伸郎, * 福田英臣*
}

1. In the isolated frog spinal cord, methionine-enkephalin ( $\mathrm{ME}$, up to $3 \times 10^{-5} \mathrm{M}$ ) hyperpolarized the resting ventral and dorsal root potentials.

2. These hyperpolarizations remained even under $\mathrm{Ca}^{2+}$-free conditions.

3. ME depressed the fast component of the electrically stimulated spinal reflex and enlarged the following depolarizing component.

4. Morphine $\left(10^{-4} \mathrm{M}\right)$ had no apparent ME-like effects.

5. ME may directly and indirectly affect the motoneuron and modulate the spinal motor activity in the frog spinal cord.

本報告は Comp. Biochem. Physiol., Vol. 83 C (2)，245-251（1986）に発表.

* 東京大学薬学部書性薬理学教室. 